\title{
Plasma Biochemistry in Female Green Iguanas (Iguana iguana) with Calcium Metabolism Disorders
}

\author{
Z. KNOTEK ${ }^{1}$, Z. KNOTKOVÁ ${ }^{2}$, J. DOUBEK ${ }^{2}$, S. PEJŘILOVÁ ${ }^{2}$, K. HAUPTMAN ${ }^{1}$ \\ ${ }^{1}$ Small Animal Clinic, ${ }^{2}$ Department of Physiology, Faculty of Veterinary Medicine, \\ University of Veterinary and Pharmaceutical Sciences Brno, Czech Republic
}

Received August 8, 2002

Accepted March 25, 2003

\begin{abstract}
Knotek Z., Z. Knotková, J. Doubek, S. Pejřilová, K. Hauptman: Plasma Biochemistry in Female Green Iguanas (Iguana iguana) with Calcium Metabolism Disorders. Acta Vet. Brno 2003, 72: 183-189.

Twenty-two female green iguanas (Iguana iguana) diagnosed with different forms of calcium metabolism disorders were classified into three groups: females with post-ovulatory egg stasis or pre-ovulatory follicle stasis (group A), females with acute hypocalcaemia (group B) and females with metabolic bone disease (group C). Group A females had the highest mean plasma values for uric acid $(p<0.05)$ and phosphorus $(p<0.05)$ compared to groups B and C. Mean values for uric acid, ALP, ALT, AST, cholesterol, calcium and phosphorus were 351.11 $\mu \mathrm{mol} \cdot \mathrm{l}^{-1}, 0.12 \mu \mathrm{kat} \cdot \mathrm{l}^{-1}, 1.42 \mu \mathrm{kat} \cdot \mathrm{l}^{-1}, 6.81 \mu \mathrm{kat} \cdot \mathrm{l}^{-1}, 5.93,3.44 \mathrm{mmol} \cdot \mathrm{l}^{-1}$ and $7.45 \mathrm{mmol} \cdot \mathrm{l}^{-1}$, respectively. The phosphorus to calcium ratio was 2.2. Group B females had the highest concentration of AST $(p<0.05)$, the highest phosphorus to calcium ratio $(p<0.05)$ and the lowest plasma concentrations of total protein, glucose, cholesterol and calcium. The mean values for total protein, glucose, uric acid, ALT, AST ALP, cholesterol, calcium and phosphorus were $47.11 \mathrm{~g} \cdot 1^{-1}, 8.67 \mathrm{mmol} \cdot \mathrm{l}^{-1}, 233.26 \mu \mathrm{mol} \cdot \mathrm{l}^{-1}, 1.11 \mu \mathrm{kat} \cdot \mathrm{l}^{-1}, 12.14 \mu \mathrm{kat} \cdot \mathrm{l}^{-1}, 0.26$ $\mu$ kat $\cdot l^{-1}, 5.19,1.18$ and $5.65 \mathrm{mmol} \cdot \mathrm{l}^{-1}$, respectively. The phosphorus to calcium ratio was 4.8 . Group C females had mean values for total protein, uric acid, ALT, AST, ALP, cholesterol, calcium and phosphorus of $55.04 \mathrm{~g} \cdot \mathrm{l}^{-1}, 239.56 \mu \mathrm{mol} \cdot \mathrm{l}^{-1}, 1.01 \mu \mathrm{kat} \cdot \mathrm{l}^{-1}, 1.91 \mu \mathrm{kat} \cdot \mathrm{l}^{-1}, 0.89 \mu \mathrm{kat} \cdot \mathrm{l}^{-}$ $1,6.02,2.64$ and $5.40 \mathrm{mmol} \cdot \mathrm{l}^{-1}$, respectively. The phosphorus to calcium ratio was 2.0 . Plasma biochemistry is a useful tool in the diagnosis of different calcium metabolism disorders observed in green iguana females.
\end{abstract}

Reptile, secondary parathyroidism, phosphorus-calcium ratio, renal disease

Chronic metabolic problems in reptiles caused by nutritional disorders are common. Osteodystrophy is frequently diagnosed in iguanas as a consequence of calcium, phosphorus and/or vitamin $\mathrm{D}_{3}$ deficits in the diet ( $\mathrm{Z}$ wart and Van De Watering 1969; Reece et al. 1986; Scott 1992; Boyer 1996). Clinical signs associated with nutritional secondary parathyroidism, such as lethargy, constipation, general weakness, bone fractures, tremor and paresis, are often not specific. These symptoms also may accompany other infectious as well as non-infectious diseases (Troyer 1984; B oyer et al. 1996; Miller 1998; B all et al. 1999; Antinoff 2000). It has recently been observed that renal secondary hyperparathyroidism is very common in lizards (Mader 2000). Last, but not least, disease of the reproductive system in oviparous reptiles female may be associated with profound calcium metabolism disorders (Zwart 1992; B oyer 1996; Raiti 1996). As the process of ovulation and/or egg deposition fails, the enlarged ovaries or the distended oviduct will occupy most of the coelomic cavity and anorexia, lethargy, limited movement with hind leg and constipation may be present (Divers 1996; Mader 2000; Not Schläpfer 2000).

The aim of this study was to compare plasma biochemistry profiles in three groups of female green iguanas that have manifested different forms of calcium metabolism problems. 


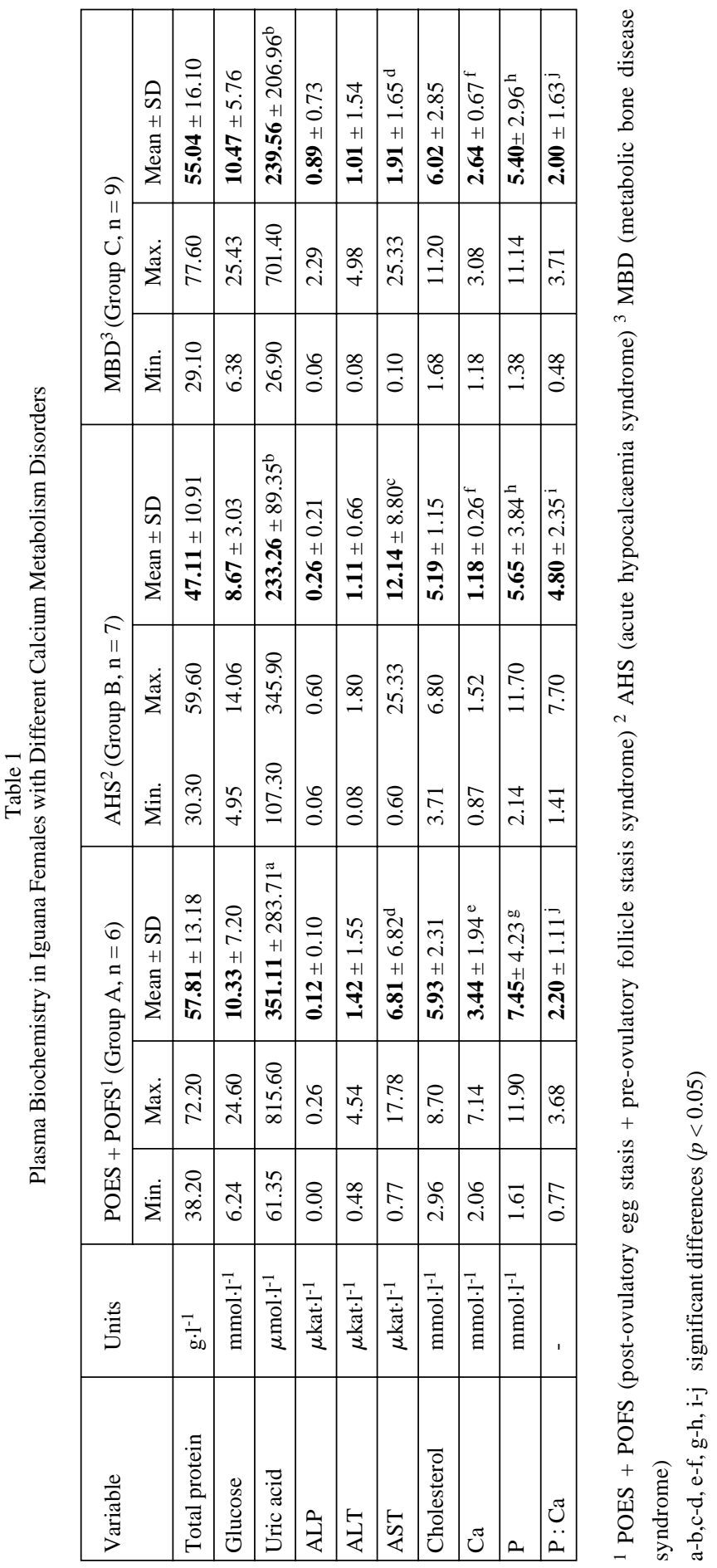




\section{Materials and Methods}

Animals

A total of 22 adult green iguana (Iguana iguana) females diagnosed with anorexia, constipation, hind leg paresis, muscle spasm and/or tremor were included in this study. Group A included 6 females with post-ovulatory egg stasis (POES) or pre-ovulatory follicle stasis (POFS) syndrome. In cases of POFS radiography revealed a distended mass occupying almost the whole coelomic cavity. By a detailed examination of the radiograph, the "bunch of grapes shape" of the mass was characteristic and the individual follicles situated on the periphery of this mass appeared as rounded structures. In cases of POES the eggs had formed a mass that was situated near the pelvis. They appeared oval, however, the shape of individual clustered ova was variable. The radiograph revealed structural changes of the femora caused by decalcification, however, without any bone fractures. Group B consisted of 7 females with acute hypocalcaemia syndrome which showed muscle spasms and/or tremors. Group C included 9 females with a typical manifestation of the chronic form of metabolic bone disease (MBD). Limited movements of the swollen hind legs were recorded in all females of this group. In two females, it was accompanied by a pliable deformation of the mandible. Anorexia and/or constipation of colonic contens were observed in 6 and 3 females, respectively. Whole body radiographs documented structural changes of the long bones of the leg. A typical picture of the bone deformation consisted of decrease in bone density, with cavity expansion and cortex thinning. Detailed examination of the radiograph revealed transverse green-stick fractures of long bones in all females of this group.

\section{Blood collection}

Blood samples were collected from the ventral coccygeal vein approximately one-third of the tail length from the cloaca (Redrobe and MacDonald 1999) by the use of 23G x 1 Luer needles. A volume of $0.5-1 \mathrm{ml}$ of blood was collected.

\section{Plasma biochemistry}

Blood samples collected in heparinized tubes containing heparin (Heparin Léčiva inj., Prague) were centrifuged immediately and plasma was removed. Plasma biochemical assays were performed within 2 hours after collection by the use of automated analyzers. The concentration of total protein (TP), creatinine, glucose, uric acid, blood urea nitrogen (BUN), alkaline phosphatase (ALP), alanine aminotransferase (ALT), aspartate aminotransferase (AST), gamma glutamyltransferase (GGT), cholesterol, phosphorus (P) was determined with a CobasMira analyzer (Roche); plasma concentrations of calcium ( $\mathrm{Ca}$ ) and potassium $(\mathrm{K})$ were determined by the Atomspec analyzer (Hilger 1550). Results were compared to normal plasma biochemical data for green iguanas (Knotek et al. 1999)

\section{Statistical analyses}

Statistical evaluation of differences in plasma biochemical values was performed by using Stat Plus software (Stat Plus, version 1.01, 1992, VÚVeL Brno, Czech Republic). Statistical significance was determined as $p<0.05$.

\section{Results}

\section{Females with POES or POFS syndrome - group A}

Clinical signs of acute hypocalcaemia manifestation were not observed in any females of this group. Mean values for total protein and glucose were within normal ranges for healthy green iguanas, being $57.81 \pm 13.18 \mathrm{~g} \cdot \mathrm{l}^{-1}$ and $10.33 \pm 7.20 \mathrm{mmol} \cdot \mathrm{l}^{-1}$, respectively. Mean concentrations of uric acid, ALT, AST and phosphorus were significantly increased, being $351.11 \pm 283.71 \mu \mathrm{mol} \cdot \mathrm{l}^{-1}, 1.42 \pm 1.55 \mu \mathrm{kat} \cdot \mathrm{l}^{-1}, 6.81 \pm 6.82 \mu \mathrm{kat} \cdot \mathrm{l}^{-1}$ and $7.45 \pm 4.23 \mathrm{mmol} \cdot \mathrm{l}^{-1}$, respectively. Mean plasma levels of ALP and cholesterol were lower than the normal range for the healthy females, $0.12 \pm 0.10 \mu \mathrm{kat} \cdot \mathrm{l}^{-1}$ and $5.93 \pm 2.31 \mathrm{mmol} \cdot \mathrm{l}^{-1}$, respectively. Mean concentration of calcium, $3.44 \pm 1.94 \mathrm{mmol} \cdot \mathrm{l}^{-1}$, was within the normal range for females, however, the phosphorus to calcium ratio was increased as a consequence of the change in plasma phosphorus levels. As compared to the normal ratio of phosphorus to calcium (0.4 1.0), in females with POFS+POES syndrome it has increased to 2.2 (Table 1).

\section{Females with acute hypocalcaemia - group B}

Mean values for total protein, glucose, ALP, cholesterol and calcium, $47.11 \pm 10.91 \mathrm{~g} \cdot \mathrm{l}^{-1}$, $8.67 \pm 3.03 \mathrm{mmol} \cdot \mathrm{l}^{-1}, 0.26 \pm 0.21 \mathrm{~m} \mathrm{~kat} \cdot \mathrm{l}^{-1}, 5.19 \pm 1.15 \mathrm{mmol} \cdot \mathrm{l}^{-1}$ and $1.18 \pm 0.26 \mathrm{mmol} \cdot \mathrm{l}^{-1}$, respectively, were lower than the normal ranges for green iguanas. Plasma concentrations of uric acid, ALT, AST and phosphorus increased to $233.26 \pm 89.35 \mu \mathrm{mol} \cdot \mathrm{l}^{-1}, 1.11 \pm 0.66$ $\mu \mathrm{kat} \cdot \mathrm{l}^{-1}, 12.14 \pm 8.80 \mu \mathrm{kat} \cdot \mathrm{l}^{-1}$ and $5.65 \pm 3.84 \mathrm{mmol} \cdot \mathrm{l}^{-1}$, respectively. As a consequence of increased phosphorus as well as decreased calcium plasma levels the phosphorus to calcium ratio has increased to 4.8 (Table 1 ). 
Females with MBD syndrome - group C

Mean values for total protein, ALP, cholesterol and calcium, $55.04 \pm 16.10 \mathrm{~g} \cdot \mathrm{l}^{-1}, 0.89$ $\pm 0.73 \mu \mathrm{kat} \cdot \mathrm{l}^{-1}, 6.02 \pm 2.85$ and $2.64 \pm 0.67 \mathrm{mmol} \cdot \mathrm{l}^{-1}$, respectively, were lower than the normal ranges for green iguanas. Plasma concentrations of uric acid, ALT, AST and phosphorus were increased to $239.56 \pm 206.96 \mu \mathrm{mol} \cdot \mathrm{l}^{-1}, 1.01 \pm 1.54 \mu \mathrm{kat} \cdot \mathrm{l}^{-1}, 1.91 \pm 1.65$ $\mu \mathrm{kat} \cdot \mathrm{l}^{-1}$ and $5.4 \pm 2.96 \mathrm{mmol} \cdot \mathrm{l}^{-1}$, respectively. As a consequence of the change in the phosphorus plasma levels the phosphorus to calcium ratio has increased to 2.0 (Table 1).

Comparison of the plasma biochemistry parameters in the three groups of females

Mean values for total protein and calcium were within the normal range in the group A only, plasma glucose levels were within the normal range for healthy green iguanas in groups A and C. All other plasmatic indices were beyond normal ranges for healthy females of green iguanas. Females of the group A had the highest mean values for uric acid and phosphorus $(p<0.05)$. The lowest mean plasma concentrations of total protein, glucose, cholesterol and calcium were found in group B females. Females belonging to this group had the highest mean concentration of AST $(p<0.05)$ and the highest phosphorus to calcium ratio $(p<0.05)$.

\section{Discussion}

Disorders of calcium and phosphorus metabolism are common problems of captive reptiles (Köhler 1996; Don oghue 1996). The most common disease of green iguanas is secondary hyperparathyroidism (osteodystrophy, osteomalacia, osteoporosis, S c ott 1992; Boyer 1996). Pathological conditions of the kidneys result frequently in calcium metabolism disorders in dogs and cats. Hyperphosphatemia and hypocalcaemia often accompany chronic renal failure in ferrets, rodents (Rijnberk and Hazenwinkel 1996; Antinoff 1998; Johnson-Delaney 1998) and in reptiles (Zwart 1992; Boyer et al. 1996; Miller 1998). Elevated serum phosphorus concentrations and changes in the phosphorus to calcium ratio occur frequently in cases of chronic renal insufficiency in reptiles. This ratio is altered at an earlier stage of renal disease when compared to uric acid concentrations (Kölle and Hoffmann 2001), however there are marked differences in renal function in mammals and reptiles (Braun 1998). It is difficult to demonstrate parathyroid hormone effects on calcium metabolism in reptiles. It was found that parathyroid hormone does not influence urinary calcium excretion in snakes (Clark and Dantzler 1972). The mammalian-type of hypocalcaemia has not been demonstrated in reptiles, including lizards (Kline and Long more 1986). However, salmon calcitonin has been used with positive effects in iguanid lizards and parathyroid hormone has increased calcium mobilisation from bones in turtles (Bélanger et al. 1973; Kline 1981). Secondary hyperparathyroidism due to a renal disorder is well known in mammals and possibly occurs also in oviparous vertebrates like birds (Lu meij 1994). It has recently been published that hyperparathyroidism of renal origin (renal secondary hyperparathyroidism) may be more common than nutritional secondary hyperparathyroidism in the green iguana (Mader 2000). Normal phosphorus and calcium concentrations in the blood serum of iguanas are 1.4 $-3.1 \mathrm{mmol} \cdot \mathrm{l}^{-1}$ and $2.5-3.5 \mathrm{mmol} \cdot \mathrm{l}^{-1}$, respectively (Knotek et al. 1999). Renal disease is assumed when the plasma concentration of phosphorus is higher than plasma calcium concentration, and, when both of these parameters are altered significantly (Kölle and Hoffmann 2001). It has been recommended to determine the plasma concentrations of uric acid, phosphorus, calcium and the phosphorus to calcium ratio in all cases of anorectic green iguanas, especially if chronic renal disease is suspected (Knotek et al. 2002).

Determining the early signs of calcium metabolism disorders in reptiles is often difficult. Chronic calcium insufficiency in green iguanas may be manifested by the same clinical signs 
as severe renal failure or the egg-binding syndrome - anorexia, lethargy, constipation and paresis (B oyer et al. 1996). Anorexia was the most frequent clinical symptom observed in iguanas with renal disease in our previous study. Constipation of the colon as a consequence of renal oedema has been observed, tubular necrosis having been confirmed in $62.5 \%$ patients (Knotek et al. 2002). In the present study, anorexia, constipation and hind leg paresis were manifested frequently by the females with post-ovulatory egg stasis (POES) or pre-ovulatory follicle stasis (POFS) syndrome. Mean concentration of calcium was within the range for healthy females, however, the phosphorus to calcium ratio was increased. High plasma levels of uric acid and phosphorus of females of this group could be caused by dehydration and renal disease. In birds and oviparous reptiles, the rise of blood calcium concentration, secondary to oestrogen-induced transport of yolk proteins to the ovary has been documented (Simkiss 1967; Lumeij 1994; Harr et al. 2001). During the period of egg-laying, calcium deposits are resorbed by osteoclastic activity and transported to the eggshell. Therefore physiological mobilisation of calcium for vitellogenesis and shell maturation may be the reasons for normocalcaemia in females of the group A. As a consequence of this phenomenon, it is not surprising that manifestation of acute hypocalcaemia has not been observed in any of females belonging to this group.

B oyer et al. (1996) described tremor as a typical manifestation of severe renal failure in $66 \%$ green iguanas. All females with acute hypocalcaemia in the present study exhibited muscle spasm and/or convulsion. Radiography confirmed the acute character of the problem, as there were no changes in the structure of long bones. Therefore, it is possible that tetany in green iguanas have resulted from a low concentration of calcium in the plasma. We expect that hypocalcaemic muscle tremor in the green iguana is caused by calcium levels of less than $2.0 \mathrm{mmol} \cdot \mathrm{l}^{-1}$. This is in accordance with the suggestion by B oyer (1996), that iguanas become hypocalcaemic if calcium levels are below $8.0 \mathrm{mg} / \mathrm{dl}\left(1.996 \mathrm{mmol} \cdot \mathrm{l}^{-1}\right)$.

Chronic metabolic bone disease was seen in green iguanas of the group $\mathrm{C}$ by swelling of the hind leg accompanied by paresis, fractures and pliable deformation of the mandible. It is not surprising that fractures, especially fractures of radius and ulna in reptiles, were frequently missed by the owners. It is not specific for reptile patients, as it is clear from alarming percentage of late diagnoses of osteodystrophy in dogs (Nečas et al. 1999). Some authors described two distinct forms of the metabolic bone disease. The first "classic" form is characterised by symptoms of a chronic disease, such as the fibrous osteodystrophy and fractures; the second form is characterised by muscle tremors and seizures (Boyer 1996). From this point of view, females belonging to the group B manifested symptoms of the latter (non-classic) MBD category, while females of the group C presented classic MBD symptoms.

Our results are in accordance with Divers' suggestion that determining blood levels of calcium and phosphorus could help in the diagnosis of renal failure in reptiles (Divers 2000). The findings of our study indicate that plasma biochemistry may help to diagnose renal failure even in gravid iguana females. Nevertheless, further work on this topic has to be done. Plasma biochemistry is a practical diagnostic tool for veterinary practice in reptiles. It helps to distinguish cases of the chronic metabolic bone disease from other forms of calcium metabolism disorders, like post-ovulatory egg stasis or pre-ovulatory follicle stasis syndrome.

\section{Biochemický profil krevní plasmy u samic leguána zeleného (Iguana iguana) s poruchami metabolismu vápníku}

Do studie bylo zařazeno dvacet dva samic leguána zeleného vykazujících př́iznaky poruch metabolismu vápníku. Ve skupině A byly samice s retencí vajec nebo stází folikulů. Průměrné hodnoty kyseliny močové, ALP, ALT, AST, cholesterolu, vápníku 
a fosforu byly $351.11 \mathrm{~m}$ mol $\mathrm{l}^{-1}, 0.12 \mathrm{~m}$ kat $\mathrm{l}^{-1}, 1.42 \mathrm{~m}$ kat $\mathrm{l}^{-1}, 6.81 \mathrm{~m}$ kat $\mathrm{l}^{-1}, 5.93$ mmol $\mathrm{l}^{-1}, 3.44 \mathrm{mmol} \quad \mathrm{l}^{-1}$ a $7.45 \mathrm{mmol} \quad \mathrm{l}^{-1}$. Poměr fosfor-vápník byl 2.2. Samice skupiny A dosahovaly signifikantně nejvyšších průměrných hodnot kyseliny močové a fosforu $(p<$ 0.05 ). Do skupiny B byly zařazeny samice $s$ příznaky akutní hypokalcémie. Hladiny celkové bílkoviny, glukózy, ALP, cholesterolu a vápníku byly u samic této skupiny 47.11 g $\mathrm{l}^{-1}, 8.67 \mathrm{mmol} \mathrm{l}^{-1}, 0.26 \mathrm{~m}$ kat $\mathrm{l}^{-1}, 5.19 \mathrm{mmol} \quad \mathrm{l}^{-1}$ a $1.18 \mathrm{mmol} \mathrm{l}^{-1}$. U samic této skupiny byly naměřeny nejnižší hodnoty celkové bílkoviny, glukózy, cholesterolu a vápníku v plasmě. Zjištěné hladiny kyseliny močové, ALT, AST a fosforu byly zvýšené na $233.26 \mathrm{~m} \mathrm{~mol} \mathrm{l}^{-1}, 1.11 \mathrm{~m}$ kat $\mathrm{l}^{-1}, 12.14 \mathrm{~m}$ kat $\mathrm{l}^{-1}$ a $5.65 \mathrm{mmol} \mathrm{l}^{-1}$. Poměr fosforvápník vystoupil na hodnotu 4.8. Průměrná hodnota AST a poměr fosfor-vápník byly nejvyšší v celé studii $(p<0.05)$. Samice zařazené do skupiny $\mathrm{C}$ vykazovaly typické známky metabolických poruch stavby kostí. Průměrné hodnoty celkové bílkoviny, ALP, cholesterolu a vápníku byly $55.04 \mathrm{~g} \quad \mathrm{l}^{-1}, 0.89 \mathrm{~m}$ kat $\mathrm{l}^{-1}, 6.02 \mathrm{mmol} \quad \mathrm{l}^{-1} \mathrm{a} 2.64 \mathrm{mmol} \quad \mathrm{l}^{-}$ 1 . Hladiny kyseliny močové, ALT, AST a fosforu v plasmě vzrostly na $239.56 \mathrm{~m} \mathrm{~mol}^{-}$ $1,1.01 \mathrm{~m} \mathrm{~kat}^{-1}, 1.91 \mathrm{~m} \mathrm{~kat} \quad \mathrm{l}^{-1}$ a $5.40 \mathrm{mmol} \quad \mathrm{l}^{-1}$, poměr fosfor-vápník byl 2.0. Analýza biochemického profilu krve se ukázala jako přínosná metoda pro diagnostiku a odlišení různých forem poruch metabolismu vápníku u samic leguána zeleného.

\section{Acknowledgements}

This project was supported by the grant of the Ministry of Education, Youth and Physical Education of the Czech Republic (No. 161/700002). The authors wish to thank to Dr. J. Pikula for his kind revision of the text.

\section{References}

ANTINOFF, N 1998: Urinary Disorders in Ferrets. In: Fudge, AM: Seminars in Avian and Exotic Pet Medicine, Renal Diseases, W.B. Saunders, Philadelphia, 7: 89-92

ANTINOFF, N 2000: Renal Disease in the Green Iguana (Iguana iguana). Proc Association Reptilian and Amphibian Veterinarians, pp. 61-63

BALL, RL, DUMONCEAUX, G, MacDONALD, C 1999: Hypertrophic Osteopathy associated with Renal Gout in a Green Iguana Iguana Iguana. Proc Association Reptilian and Amphibian Veterinarians, 5. - 9. 10. 1999, Columbus, pp. 49-50

BÉLANGER, LF, DIMOND, MT, COPP, DH 1973: Histological observtions on bone and cartilage of growing turtles treated with calcitonin. Gen Comp Endocrinol 20: 297-304

BOYER, TH 1996: Metabolic Bone Disease. In: MADER, DR (Ed): Reptile Medicine and Surgery. W. B. Saunders, Philadelphia, pp. 385-392

BOYER, TH, GETZY, D, VAP, L, INNIS, C 1996: Clinicopathologic Findings of Twelve Cases of Renal Failure in Iguana iguana. Proc. Association Reptilian and Amphibian Veterinarians, 24. - 27. 8. 1996, Tampa, p. 113

BRAUN, EJ 1998: Comparative Renal Function in Reptiles, Birds, and Mammals. In: FUDGE, AM(Ed): Seminars in Avian and Exotic Pet Medicine, Renal Diseases, W.B. Saunders, Philadelphia, 7: 62-71

CLARK, NB, DANTZLER, WH 1972: Renal tubular transport of calcium and phosphate in snakes: role of parathyroid hormone. Amer J Physiol 223: 1455-1464

DIVERS, SJ 1996: Medical and Surgical Treatment of Pre-ovulatory Ova Stasis and Post-ovulatory egg Stasis in Oviparous Lizards. Proc. Association Reptilian and Amphibian Veterinarians, 24. - 27. 8. 1996, Tampa, pp. 119123

DIVERS, SJ 2000: Reptilian renal and reproductive disease diagnosis. In: FUDGE, AM (Ed): Laboratory medicine: avian and exotic pets. W.B. Saunders, Philadelphia, pp. 217-219

DONOGHUE, S 1996: Nutrition of the Green Iguana (Iguana iguana). Proc Association Reptilian and Amphibian Veterinarians, 24. - 27. 8. 1996, Tampa, pp. 99-106

HARR, KE, ALLEMAN, R, DENNIS, PM, MAXWELL, LK, LOCK, BA, BENNET, RA, JACOBSON, ER 2001: Morphologic and cytochemical characteristics of blood cells and hematologic and plasma biochemical reference ranges in green iguanas. J Am Vet Med Assoc 218: $915-921$

JOHNSON-DELANEY, CA 1998: Disease of the Urinary System of Commonly Kept Rodents: Diagnosis and Treatment. In: Fudge, A.M. Seminars in Avian and Exotic Pet Medicine, Renal Diseases, W.B. Saunders, Philadelphia, 7: 81-88

KLINE, LW, LONGMORE, GA 1986: Deterination of calcitonin in reptilian serum by heterologous radioimmunoassay. Gen Comp Endocrinol 61: 1-4

KNOTEK, Z, KNOTKOVÁ, Z, HALOUZKA, R, MODRY, D, HÁJKOVÁ, P 1999: Diseases of Reptiles (Nemoci plazů), ČAVLMZ, Brno, 275 p. (in Czech) 
KNOTEK, Z, HAUPTMAN, K, KNOTKOVÁ, Z, HÁJKOVÁ, P, TICHÝ, F 2002: Renal disease haemogram and plasma biochemistry in green iguana. Acta Vet Brno, 71: 333-356

KOHLER, G 1996: Krankheiten der Reptilien und Amphibien. Eugen Ulmer Verlag, Stuttgart, 166 p.

KÖLLE, P, HOFFMANN, R 2001: Renal Diseases in Reptiles: Diagnostic Tools. Proc Abstr EAZA Scientific Meeting, 23. - 26. 5. 2001, Rotterdam, pp. 67-69

LUMEIJ, JT 1994: Endocrinology. In: RITCHIE, BW, HARRISON, GJ, HARRISON, LR (Ed): Avian Medicine: Principles and Application. Wingers Publ., Lake Worth, pp. 582-606

MADER, DR 2000: Understanding Calcium. Proc. Association Reptilian and Amphibian Veterinarians, 17. - 21. 10. 2000, Reno, pp. 153-154

MILLER, HA 1998: Urinary Diseases of Reptiles: Pathophysiology and Diagnosis. In: FUDGE, AM (Ed): Seminars in Avian and Exotic Pet Medicine, Renal Diseases, W.B. Saunders, Philadelphia, 7: 93-103

NEČAS, A, DVOŘ́A, M, ZATLOUKAL, J 1999: Incidence of osteochondrosis in dogs and its late diagnosis. Acta Vet Brno 1999 68: 131-139

NOT SCHLÄPFER, I 2001: Follicular Stasis in the Green Iguana (Iguana Iguana). Proc. Abstr. EAZWV $3^{\text {rd }}$ Scientific Meeting, 31. 5. - 4. 6. 2000, Paris, pp. 291 - 295

RAITI, P 1996: Dystocia in Colubrid Snakes. Proc. Association Reptilian and Amphibian Veterinarians, 24. - 27. 8. 1996, Tampa, pp. 93 - 95

REDROBE, S, MacDONALD, J 1999: Sample collection and clinical pathology of reptiles. Veter Clin North Amer - EAP 2: 709-730

REECE, RL, DICKSON, DB, BUTLER, R 1986: An Osteopetrosis-like Condition in a Juvenile Rhinocerus Iguana (Cyclura cornuta). Australian Vet Journal 63: 343-344

RIJNBERK, A, HAZEWINKEL, HAW 1996: Parathyroids. In: RIJNBERK, A (Ed): Clinical Endocrinology of Dogs and Cats. Kluwer Academic Publ., Dordrecht, pp. 167-175

SCOTT, PW 1992: Nutritional Diseases In: BEYNON, PH, LAWTON, MPC, COOPER, JE (Ed).: Manual of Reptiles. BSAVA, Cheltenham, pp. 138-152

SIMKISS, K 1967: Calcium in Reproductive Physiology: A Comparative Study of Vertebrates. Chapman and Hall, London, pp. 214220

TROYER, K 1984: Diet selection and digestion in Iguana iguana: The importance of age and nutrient requirements. Oecologia 61: 201-207

ZWART, P 1992: Urogenital System. In: BEYNON, PH, LAWTON, MPC, COOPER, JE (Ed): Manual of Reptiles. BSAVA, Cheltenham, pp. 117-127

ZWART, P, Van De WATERING, CC 1969: Disturbance of Bone Formation in the Common Iguana (Iguana iguana L.): Pathology and Etiology. Acta Zool Pathol Antverpiensia 48: 333-356 